European journal of American studies

Special Issue: Re-Queering The Nation: America's

Queer Crisis

\title{
The Missing Colors of the Rainbow: Black Queer Resistance
}

\section{Elena Kiesling}

\section{OpenEdition \\ Journals}

Electronic version

URL: https://journals.openedition.org/ejas/11830

DOI: $10.4000 /$ ejas. 11830

ISSN: 1991-9336

Publisher

European Association for American Studies

\section{Electronic reference}

Elena Kiesling, "The Missing Colors of the Rainbow: Black Queer Resistance", European journal of American studies [Online], 11-3 | 2017, document 13, Online since 26 January 2017, connection on 08 July 2021. URL: http://journals.openedition.org/ejas/11830 ; DOI: https://doi.org/10.4000/ejas.11830

This text was automatically generated on 8 July 2021.

Creative Commons License 


\title{
The Missing Colors of the Rainbow: Black Queer Resistance
}

\author{
Elena Kiesling
}

\section{Introduction}

1 The shootings of black men, the beatings of black women, the murders of black trans women, and the retraction of voting rights for the African American community in some U.S. states stand in sharp contrast to the presumably progressive gains of an LGBT movement which more than once claimed that "gay is the new black." ${ }^{1}$ This is not only a dangerous analogy which lacks any profound grounding, it also leads to a discourse that draws a clear boundary between two separate communities and movements-one black, one queer-placing the former clearly on the margins of a society that happily embraces the latter. What happens to the black queer experience when black is increasingly used as an antipode to queer, when black bodies are erased from queer scholarly discourse, activism, and neighborhoods while queer bodies are welcomed as a sign of progress and safety? For whom does this whiteness signify safety?

These questions build the background for a critically queer analysis of black queerness at a time when white queerness and black masculinity are at the center of the public debate. Nneka Onourah's The Same Difference (2015) critically engages with the interlocking identifications of blackness, queerness, and gender. The film is contextualized in relation to the history of queerness from the social movements of the 1960s through the HIV/AIDS crisis of the 1980s to today's \#BlackLivesMatter activism against state-sanctioned violence.

The resulting dialogue between the cultural representations and the material conditions in which they were formed challenges the dominant mainstream queer movement in which "the contemporary white gay male clone" (Muñoz 60) is the poster boy of white middle-class gayness and questions the presumed heterosexuality of the black community. It reconstructs a paradigm for radical queer politics in the force-field 
of traditional notions of identity and community as potential for collective action, and queerness as a destabilizer of both. By doing so, it adds to existing scholarship around the complex relationship between identity and community as well as recent scholarship in Black Queer Studies. Ultimately, the discourse surrounding black queerness, re-queers the nation by, paradoxically, bringing queerness back into a marginal position from which it can be critical of the state. Only within this complex array of power that generates voices from the margins will queerness find validity as a political strategy, a tool for critical thinking, a way of active resistance, and a basis for community action.

4 Through an assemblage of reading and writing practices that, methodologically, wade knee-deep in the messy terrain of cross-disciplinary inquiry-from critical race studies, through queer of color critique, woman of color feminism, and visual cultural studiesthis article engages in a variety of critical perspectives rather than finding safety in single-issue approaches that ignore the multi-faceted nature of social struggle outside of the hetero- and homonormative ${ }^{2}$ hegemonic framework.

The paper begins with the contextualization of identity and community in general and queerness and blackness in particular in a supposedly colorblind, postracial era with a special focus on the \#BlackLivesMatter movement. It then continues to outline the distinction between the development of blackness and queerness in the social movements of the 1960s and 1970s to describe how the former has become prone to criminality while the latter has become embedded in whiteness. The central part of this paper is the analysis of Nneka Onourah's 2016 documentary The Same Difference that addresses the intersections of queerness, blackness, and gender in a unique and inspiring way.

The paper concludes with an outlook on how the nation can be re-queered through marginalized voices that connect queerness to other forms of marginalization and through a queer theory that is informed by, not opposite to, women of color feminism and critical race studies.

\section{Contextualization}

Struggle around notions of identity and community have a long-standing history in the socio-political and cultural landscape of the U.S. Community on the basis of a fixed, essential identity has been heavily debated in the wake of a critique of identity politics and challenged by a wide variety of women of color feminists, queer of color scholars and radical activists across the board that saw the limits of homogenization. ${ }^{3}$ Especially women of color feminists have challenged identity politics and argued for collective activism based on shared similarities across difference. Kimberley Crenshaw explains: "[T]he problem with identity politics is not that it fails to transcend difference... but rather the opposite-that it frequently conflates or ignores intragroup differences" (1242). However, identity-centered action and by extension community-focused rhetoric continue to surface in political activism whenever the imagined core of a community is at stake because both, identity and community, nevertheless hold powerful positions in the socio-cultural and political realm. Although people still organize around shared aspects of identity, collective identity carries the dangers of homogenization in favor of a positive life-script that erases possible differences within the community (Appiah). Identity is never singular, and never 
essential. The danger of erasing intra-group differences is clearly recognizable in the actions of a mainstream queer community that focuses on marriage, access to state institutions (e.g. the military), and the incorporation into a neoliberal, homonormative, and colorblind society in general. Lisa Duggan coined the term homonormativity in 2003 to describe a form of queer "politics that does not contest heteronormative assumptions and institutions but upholds and sustains them" (50). Such politics lead to an understanding of queerness as (white) identity, rather than critical of the hegemony of whiteness, because queerness has to clearly position itself as worthy of integrating into normative society, rather than being eccentric to it. The arguments held up in favor of such politics frequently propose an analogy between queerness and race (other than whiteness), in which queers are among the last recipients of certain civil rights that have already been bestowed on people of color. Besides the irritating assumption that the fight for racial justice is historically complete, the additional pitfall of such a lack of intersectional thinking is the erasure of intra-group difference that Crenshaw bemoans. In light of the growing legal achievements of a politically mainstream queer movement in contrast to the lack of liberation and equality for a growing number of black Americans-attack on voting rights, criminalization-it becomes clear that queerness and blackness have not only historically been rendered parallel movements but continue to do so.

From the social movements of the 1960s and 70s, through the HIV/AIDS crisis of the 1980s and 1990s, until today's fight for incorporation into the nation-state, queer dynamics have always been an integral part of American culture and history. Whether they have been silenced or hidden, censored or celebrated, they have played an active role in shaping society although the meaning of queerness has certainly changed. A derogatory term for homosexuals in the beginning, queer has later been reclaimed by HIV/AIDS activist and is currently used as an umbrella term for LGBT, a term for nonheterosexual or gender non-conforming practices, or as a radically non-identitarian, contradicting, and politically challenging term with a keen sense on positionality. Although queer is used in all three contexts, at times interchangeably, I deploy queer in a rather radical sense and attempt to use its most pertinent characteristics from the most powerful works in a queer of color critique. This implies an understanding of queerness as radically critical of hetero-/homonormative politics that aim at incorporation into state-structures instead of challenging the unequal distribution of life-chances based on these structures. Cathy Cohen goes even so far as to describe blackness as queerness. Through her analysis of the brutal murder of Derrion Albert, Cohen reminds us of the need for such a move from a traditional reading of queerness as based on sexual practices toward a more radical reading of queerness including nonnormative racial and ethnic identities within a neoliberal political context (Democracy). I want to incorporate her understanding of queerness into the critical investigation of the intersection of blackness and queerness because as much as queer dynamics have shaped the social and cultural markup of U.S. society, so have racial dynamics, especially blackness. ${ }^{4}$ Saidiya V. Hartman defines blackness

in terms of social relationality rather than identity, thus blackness incorporates subjects normatively defined as black, the relations among blacks, whites, and others, and the practices that produce racial difference. Blackness marks a social relationship of dominance and abjection and potentially one of redress and emancipation. It is a contested figure at the very center of social struggle. (57) 
The concept of social relationality rather than identity enables to envision a framework in which "power circulates in complicated ways rather than unidirectionally" (Friedman 63). It also creates an understanding of blackness that is aware of the multidirectional forces of power that shape blackness. The complexity aligns well with an understanding of queerness that is equally aware of the functions of complex, sometimes oppositional, power structures. Yet, an understanding of queerness as critical of identity needs to be aware of the fact that the regulatory function of the norm that creates the subject affects blackness differently than it affects queerness. ${ }^{5}$ Cohen quite clearly states in her critique of queer politics, that "some traditional social identities and communal ties can, in fact, be important for one's survival" ("Punks" 34). The crucial intersection of both movements-one black, one queer-is often ignored for the benefits of political activism that recurs to Gayatri Spivak's strategic essentialism or even outright identity politics which is blind to intra-group differences. Strategic essentialism works well at necessary moments when political recognition is the ultimate goal. The pitfalls of such a strategy, however, is the homogenization of a group identity that is far from homogenous at all. Stuart Hall argues that "[t]he essentializing moment is weak because it naturalizes and dehistoricizes difference" (111). The essentializing moment of the queer community that describes queer political activism in the present comes at the expense of other aspects of identification, such as race, class, and gender. The result is an either or bind, in which blackness and queerness are treated as separate but analogous identities. This creates a void at the intersection of both that makes queer of color people invisible and does not do justice to their lived experiences, their creative, political, and critical work. It also does not enable a critical queerness.

As the movements for black liberation and queer equality have drifted apart, there is still room for debate at the intersection of race and sexuality, both historically and contemporary. Blackness has been enslaved, attacked, freed, celebrated, appropriated, and claimed in U.S. history. In a postmodern, neoliberal, purportedly colorblind U.S. society, headed by a black President, it is still all of the above. Interestingly, it is very seldom queered. What does this mean for black queerness? Black queerness for the most part remains a side note; a marginal character to the main cultural, social, and political players of queerness and blackness although black queerness has shaped important periods of U.S. history.

Arguably one of the most influential literary periods, the Harlem Renaissance, was significantly shaped by queer artists of color such as Countee Cullen, Claude McKay, Langston Hughes, and Richard Bruce Nugent. These writers and other artists formed the cultural aesthetics of the 1920s despite or because of their overtly and covertly queer black lives at a time when neither queerness nor blackness were embraced by society. Decades later, in the 1960s, an openly black gay civil rights activist, Bayard Rustin, was at the forefront of the civil rights movement, while other queer civil rights activist, such as Pauli Murray, have worked rather unnoticed. Although black queer characters have made considerable contributions to U.S. culture and society, black queerness has not become part of the collective memory of the nation. ${ }^{6}$

In $\mathfrak{a}$ dangerous turn away from intersectionality, the important crossings of blackness and queerness are overlooked, preventing a focus on the multifaceted and often overlapping oppressive power structures that are shaped by gender, class, race,

European journal of American studies, 11-3 | 2017 
and sexuality, simultaneously. Christina Hanhardt reconstructs the complex dynamics of queer activism in her book Safe Space from the early homophile movements, through gay liberation, and today's activism that led to a change in focus from multi-issue activism focusing on police brutality across genders, race, and sexuality, to the primacy of whiteness, safety, and visibility. She argues that the increasing focus on safety and visibility in queer activism led to the construction of a white queer identity and community that positioned itself against people of color who were seen as the most common perpetrators of violence against queers and not the victims of violence.

The shift in focus from fighting police brutality to mainstream queer politics centering on whiteness is also reflected in the collective memory of a mainstream queer community. One of the best known examples of gay activism, the Stonewall Riot in 1969 , has become a highly marketed moment that is used to perpetuate a fictive ${ }^{7}$ beginning, burnt into public memory as the event that marked the onset of the fight for liberation among gays and lesbians. It is not remembered as one moment in a series of events confronting violence against those most marginalized-queers and of colorstaged by those most affected by state-sanctioned violence. At the forefront of the protest were not young white college boys, as Roland Emmerich's 2015 movie Stonewall suggests but queer and trans people of color, poor queers, and non-queer people of color that were frustrated with the criminalization of and the violent reactions toward them. Hanhardt clarifies:

the memory of 'Stonewall'... often omits the facts that it was a collective challenge to the police and that it was just the latest clash in an ongoing struggle. Furthermore, gay liberation organizations that arose in the aftermath of the riots believed that protection from the police would depend on their forming coalitions with other social movements, including Black power, radical feminism, and Third World decolonization. (1)

14 Turning the Stonewall Riots into a whitewashed memory of gay liberation is a cruel indictment of the workings of queer people of color all across the U.S. Yet, it is not only the erasure of color from a mainstream movie that is so disturbing. People intricately involved in these movements are silenced, censored, or worse erased from queer history as much as they are erased from the actual sites of the riots. The eradication of queer people of color from the neighborhood in which the Stonewall Inn is located is even more alarming. The queer and trans people of color that flocked the area around the Christopher Street Piers in New York City in the 1960s and 1970s and into the 1990s have been forced out of the area through massive gentrification measures and its usual suspects: increased police presence, skyrocketing rents, and the closing down of queer places in favor of chain-stores. For the white neighbors and the predominantly white tourists, the erasure of queer people of color signifies safety. Hanhardt argues that the historical developments of queer activism and the economic policies of the neoliberal city have led to the development of an analogy between race and sexuality in which queerness can only function if it is dispelled from other markers of identity such as race, class, and gender.

The silencing of black voices within queer activism and the refusal to acknowledge multiple intersecting aspects of identification can be seen throughout U.S. history. David Eng calls this "queer liberalism," describing the "contemporary confluence of the political and economic spheres that forms the basis for the liberal inclusion of particular gay and lesbian U.S. citizen-subjects petitioning for rights and recognition before the law" (3). These particular gay and lesbian U.S. citizen-subjects 
are clearly marked by whiteness which Eng explains against the background of three landmark U.S. Supreme Court rulings, Lawrence vs. Texas (2003), Brown vs. Board of Education (1954), and Loving vs. Virginia (1967):: "By analogizing Lawrence to Brown and Loving, gay and lesbian activists configure queer liberalism as a political project in the present while consigning racism as a political project of the past.... In other words, queer liberalism functions not in opposition to but with the logic of colorblindness that deems the racial project historically "complete"' (17). The historically completion of the racial project thus enables a thinking along the lines of 'gay is the new black.'

Attempts to bring both blackness and queerness in conversation with each other in the socio-cultural and political realm have for the most part been difficult to establish, except for some scholars, activists, and organizations that continue to write in the field. Nevertheless, the socio-political movements of blacks and queers remain severed and the rift between both communities grows with every new articulation of gay equals black analogies, homophobic utterances of leading black community institutions, the silence on racial equality from leading LGBT organizations, or the calls for safety within gay neighborhoods that target people of color and economically deprived populations.

\section{3. \#BlackLivesMatter}

\#BlackLivesMatter is a notable exception that does not eschew the messy terrain of politics at the intersection of queerness and blackness. The movement was started in 2012 after Trayvon Martin's death as "a response to the anti-Black racism that permeates (U.S.) society" (Garza). It has since continued to challenge police violence against African Americans across the U.S. and using queerness as a framework to broaden, support, and challenge blackness in its political activism without centralizing mainstream queer activism. \#BlackLivesMatter is a movement and collective action that refuses to take a single issue approach to politics in response to Audre Lorde's comment that, "we do not lead single-issue lives" (138). It centers blackness while employing a queer framework to recognize and acknowledge the multiple intersections of both blackness and queerness up to the point when Cohen's statement that blackness is already queer becomes viable. Its mission statement reads: "Black Lives Matter affirms the lives of Black queer and trans folks, disabled folks, black-undocumented folks, folks with records, women and all Black lives along the gender spectrum. It centers those that have been marginalized within Black liberation movements. It is a tactic to (re)build the Black liberation movement." ${ }^{10}$ By doing so, it is reminiscent of Harper's understanding of "[q]ueer theory [as] an articulating principle functioning in, across, between, and among various social domains and political experiences, and it is therefore consciously provisional and dynamic, strategic and mobilizing, rather than prescriptive or doctrinal" (Harper et al. 1).

The request for queer politics to focus on intersecting mechanisms of oppression and not solely on queerness as predominantly white and class privileged (Cohen, "Punks") is still not actualized. Major queer organizations remain ignorant of race in their attempts to find incorporation into a colorblind society instead of attempting to queer the nation-state in relation to race. ${ }^{11}$ \#BlackLivesMatter has reclaimed a queer framework that can indeed be critical of the state without being incorporated by it. Patrisse Cullors, Opal Tometi, and Alicia Garza, founders of the 
hashtag and accompanying movement identify as black queer women and bring queerness back into the struggle for black liberation through their work, because "[s]traight men, unintentionally or intentionally, have taken the work of queer Black women and erased [their] contributions.... [B]eing black queer women in this society... tends to equal invisibility and non-relevancy" (Garza). \#BlackLivesMatter is thus not a call to the specificities of black life. It is a simple call to the inviolability of black life and the black body that thinks race and sexuality together, while being attentive to the different histories of each. By vowing to embrace queerness and blackness simultaneously, while clearly focusing on the attacks on black lives, queerness becomes a critical tool for those marginalized by a dominant, heteronormative, heterosexist, patriarchal, and racist society. \#BlackLivesMatter does not empower a utopian feeling for queer belonging because this belonging is framed by the privilege of whiteness. Even worse, it has actively attacked blackness, positing queerness as everything but black. A reading of blackness through a queer lens thus centers queerness as it currently positions itself-before blackness. A reading of queerness through a framework that centers blackness, however, brings both race and sexuality into conversation with each other rather than against each other.

\section{The Missing Colors of the Rainbow}

\#BlackLivesMatter is an urgent response to the violence experienced by black people at the hands of police. 1,134 black men have died at the hands of police in 2015. 21 trans women of color have been murdered in the same year. There is little doubt that the numbers will not diverge much in 2016. Despite the erasure of blackness in most of mainstream queer organizing, what then does queerness have to do with the mass shootings of black men and women, the murders of black trans women, and the attack on voting rights and civil rights for the African American community?

The historical erasure of black queerness from memory feeds well into the current moment of colorblindness, or what Jared Sexton almost ironically describes as people-of-color-blindness, an unwillingness to see people of color. Omi and Winant argue that colorblindness enables neoliberalism (15) and both enforce upon the U.S. a socio-political and cultural attitude that eschews to address the continuing racism and injustice at the state-level appropriately. "In America, it is traditional to destroy the black body-it is heritage," writes Ta-Nehisi Coates in Between the World and Me (103). The black body speaks from a position of marginalization ever since African slaves arrived on American soil and Barack Obama's presidency could not change this. The words of Coates resonate even more deeply at a moment when the black body, as individual agent and abstract concept, is widely attacked by the state. Trayvon Martin, Eric Garner, Tamir Rice, Michael Brown, Sandra Bland-these names resound with the tragic deaths of innocent black bodies at the hands of white police officers. And the list continues to grow. But the names of individual people's deaths at the hands of criminal law enforcement are not the only names that resound. The immense amount of black people incarcerated within U.S. borders adds a distinctiveness to the precariousness of black life. Michelle Alexander reminds her readers that the logic of colorblindness is extremely at fault when looking at the criminal justice system. In an interview with DemocracyNow! she states: "[0]f course... young white kids who make mistakes, commit misdemeanors and jaywalking and smoke weed, they are able to go off to college if they 
are middle-class. But if you're poor or you live in the hood, the kinds of mistakes [can] actually cost them their lives" ("Roots"). The result is that "[m]ore African American adults are under correctional control today-in prison or jail, on probation or parolethan were enslaved in 1850, a decade before the Civil War" (Alexander 180). Alexander and Coates, among other black intellectuals, academics, artists, and activist, make their voices be heard in their various calls for black liberation because the racial ideology of colorblindness does not mean being blind to race as much as it means being blind to racial inequality. The result of such blindness to racial inequality can be seen all throughout U.S. history from slavery, to Jim Crow, to the mass incarceration of the present. Alexander explains:

Arguably the most important parallel between mass incarceration and Jim Crow is that both have served to define the meaning and significance of race in America.... Slavery defined what it meant to be black (a slave), and Jim Crow defined what it meant to be black (a second-class citizen). Today mass incarceration defines the meaning of blackness in America: black people, especially black men, are criminals. That is what it means to be black. (197)

\subsection{Black Criminals, White Queers}

This resonates with Hanhardt's genealogy of the spatial dynamics of gay activism and the prerogative of safety for the white queer subject. In the analogy of race and queerness, the determining factor of differentiation is criminality. Queerness then, needs to define itself as anything but the criminal, anything but black. The black body remains criminal, while the queer body moves into the realm of citizenship. "[T]he conflation of blackness with crime did not happen organically; rather, it was constructed by political and media elites as part of the broad project known as the War on Drugs. In the era of colorblindness, it is no longer permissible to hate blacks, but we can hate criminals. Indeed, we are encouraged to do so" (Alexander 199). Such arguments encourage anti-blackness within current mainstream queer politics "and reproduce anti-blackness as a foundational structure of US Americanness" (Bassichis and Spade 193). Dean Spade and Morgan Bassichis claim: "Because 'blackness' and 'criminality' are wedded in the US lexicon... any claims to not being a criminal-or on the flipside, to being a citizen-must literally be made on the backs of black people" (193). While the black body is increasingly violated in the U.S., the queer body is gradually welcomed into full citizenship. Queer U.S. citizens are granted more rights to life (same-sex marriage, DADT) while black Americans are denied rights to life on a daily basis. As such, queer life is constitutive of black death as it ignores those queer subjects who are both black and queer. The criminalization of queerness, especially during the governmental neglect of HIV/AIDS victims in the 1980s has given way to an increasing integration into a hegemonic position inside the nation-state. The primacy of death has given way to the primacy of life. This is certainly not a contingent, deracialized move. The nation-wide decriminalization of sodomy in 2003 marked the ultimate end to the criminalization of queer bodies. The queer body that is detached from criminality, however, is first and foremost white, before it is queer. It is clearly framed as the one who is violated by criminals and not as the perpetrator. On the other hand, the black body is almost always framed as criminal and "black criminality [has] become the most significant and durable signifier of black inferiority in white people's minds since the dawn of Jim Crow" (Gibran 3). At the same time "[s]tate violence against black men-against poor, dark, mainly male bodies-is one of the most 
continuous and seemingly central aspects of the U.S. racial system" (Omi and Winant 145).

The separation between queer organizations and black organizations, despite the intersection of both communities and movements, thus follows a cruel logic of antiblackness that has been all too familiar in U.S. history. At a moment when queerness is celebrated in front of the Supreme Court-through the appropriation of black history by chanting 'We Shall Overcome'-legalized by the same institution, welcomed into public life by the media and a black President granting support, blackness is everything but. It is attacked by the police and right-wing politicians, deprived of voting rights by the courts, thwarted by an economic system that increasingly cuts social services while supporting privatization, and ultimately left to die. This leaves blackness in a state of emergency, while queerness steers unapologetically toward the safe haven that is full equality and consumer consumption. It also drives a wedge between two imaginary communities-one black, one queer-in which the former one is marked by straightness, while the latter one is marked by whiteness.

\subsection{Anti-Blackness in Queer Politics}

There are three key events that are representative of the anti-blackness in mainstream queer politics. These events are emblematic for the erasure of blackness within mainstream queer organizing and point to a political strategy that is even more possible through colorblindness.

The first event is the passage of Proposition 8 in California in $2008^{12}$ which revealed the blatant racism of the white queer community. Leading LGBT organizations and queer spokespeople blamed homophobia within the black community for the passing of Proposition $8 .{ }^{13}$ Another example of the lack of intersectional discourse can be found in the biased push toward stronger hate-crime legislation from mainstream queer organizations. One of the most famous examples is the signing of the Matthew Shepard and James Byrd Jr. Hate Crimes Prevention Act in 2009. The bill, which is most widely know as the Matthew Shepard Act (once again centering the white gay male, while dropping the name of the black male that was lynched) was passed as an attachment to a Department of Defense bill. This results in further funding for state institutions like the police and the military that ultimately target those that the act attempts to protect, or, in the case of the military, enable violent acts upon populations of color outside of the U.S. (Spade 2008). The third key element is the silence of leading LGBT organizations on the mass-incarceration of black bodies. Jared Sexton explains why such lack of attention to blackness will ultimately lead to failure:

[E]very attempt to defend the rights and liberties of the latest victims of state repression will fail to make substantial gains insofar as it forfeits or sidelines the fate of blacks, the prototypical targets of the panoply of police practices and the juridical infrastructure built up around them. Without blacks on board, the only viable political option and the only effective defense against the intensifying crossfire will involve greater alliance with an anti-black civil society and further capitulation to the magnification of state power. (48) they truly aspire change. However, the identity lines of leading LGBT organizations are often clear-cut with little potential for intersectional thinking. 
The workings of the current mainstream queer movement can be aligned with what Daniel HoSang calls political whiteness. Political whiteness describes a process through which "political identifications and communities become determined by the narrative of racial difference" (54). A queer political movement clearly follows the logic of political whiteness and positions itself as a stable concept that is only sustainable when race, class, and gender are rejected as social formations.

The blindness toward racial difference within queer activism and politics does not stop at U.S. borders. The racial and ethnic differences within a queer community have also been erased in favor of a whitewashed image of the community that can be used as a marker of progressiveness when compared to non-white, non-Western countries. This is reflective of what Puar termed homonationalism in extension of Lisa Duggan's homonormativity. A colorblind society that leads to the exclusion of people of color, some of them queer, often goes hand in hand with a homonormative structure in which the norm is not only marked by sexuality, but also by race. Puar's amalgamation of homonormativity and nationalism to homonationalism points to the instrumentalization of the queer community as an evaluative tool for the nation's state of modernity compared to other, less progressive, less modern nation-states (Puar). Queerness becomes an emblem of state power, not a powerful force critiquing state power as queer originally hinted at.

The following analysis of a documentary about black lesbian experiences reframes the critical potential of queerness through some of its most marginal members, black queer women. Within these contexts, queerness functions as a destabilizer of identity while remaining aware of the material realities that affect some identities more than others. It is used as a tool to actively engage in coalitional work and criticize dominant assumptions of what it means to be queer and/or black, placing queerness back into an oppositional position from which it can be critical of the nation.

\section{Black Queer Aesthetics}

The creative attention to the deviancy of black queerness enables a critical questioning of the relationship between race and sexuality in the socio-cultural and political realm while also working against the erasure of black queerness. It allows for a reading of culture, politics, and activism that puts marginalized voices into focus while constantly and consistently challenging the definitions and positions of blackness and queerness at a time when they are often, sometimes unknowingly, defined in opposition to each other.

The analysis of popular culture does not simply reiterate existing theory, but enlarges and elaborates existing theory by writing marginalized voices and materials into it. Black queer aesthetics, although not always explicitly, also function as political engagements that push the boundaries of queerness, blackness, masculinity, and femininity. Popular culture as theory, however, also poses a risk. Stuart Hall reminds his readers that "[popular culture] is the space... where control over narratives and representations passes into the hands of the established cultural bureaucracies, sometimes without a murmur. It is rooted in popular experience and available for expropriation at one and the same time" (108). The expropriation happens when the margins tell critical stories of the mainstream. By doing so, these stories nevertheless place the mainstream into the center. The film analyzed here stays within the realm of 
the margins, because it embraces an "aesthetic of blackness [that is] strange and oppositional" (hooks 72). By doing so, the film resonates well with what James Baldwin expressed in an interview in 1961:

All you are ever told in this country about being black is that it is a terrible, terrible thing to be. Now, in order to survive this, you have to really dig down into yourself and re-create yourself, really, according to no image which yet exists in America. You have to impose, in fact-this may sound very strange-you have to decide who you are, and force the world to deal with you, not with its idea of you. (Stanley and Pratt 5-6)

It is not only the aesthetic of blackness that is strange and oppositional, it is also the aesthetic of queerness that is oppositional. Centering black queer women, honors not only Baldwin's claim to decide who you are, it also credits Stuart Hall's assertion that "it is to the diversity, not the homogeneity, of black experience that we must give our undivided creative attention" (111-112). This diversity includes queerness.

\subsection{Black Queer Women}

Although black women are also the targets of violence and discrimination within the U.S., the black body that is framed as the victim of police violence and the criminal justice system is often male. Yet, if the lens through which black life is most commonly framed is first and foremost assumed to be male, and the lens through which queerness is framed is almost always white, then black queer women are marginalized within both the fight for black liberation and queer equality. This multiple marginalization offers opportunities to speak from a social experience that does not stop at being female in a patriarchal society as much as it does not stop at being black in a sea of white privilege. Cohen describes the intersection of womanhood, queerness, and blackness in her article "Punks, Bulldaggers, and Welfare Queens" which, despite its original publication in 1997, is still relevant today for discussing the critical potential of queerness as a marker of social justice at the intersection of queerness and blackness. The complexity of this intersection of blackness and queerness is the starting point for a discussion of The Same Difference that challenges the centrality of maleness in the discourse surrounding black liberation, while at the same time acknowledging its unique position. Placing black queer women in the center of the frame not only aesthetically through the use of camera techniques, but also metaphorically through the contents the film's interviews, at a time when black masculinity and white queers are at the forefront of struggle, is a courageous and revolutionary act.

\subsection{The Same Difference}

The Same Difference is a 2015 performative documentary from director and producer Nneka Onourah in which she highlights black queerness and discusses discriminatory practices against nontraditional gender performances within the black lesbian community. It is a critical engagement with the messy and complicated realities of black female subjectivity as it is performed in relation to queer desire. Onourah juxtaposes interviews with a variety of talking heads from prominent black lesbians to unknown black lesbians to capture the diversity of gender identifications within the 
community and counter the lack of black lesbian representations in the media. Although the documentary introduces studs, femmes, femme aggressive, AGs, and bisexuals, it clearly focuses on studs ${ }^{14}$ in the remaining parts of the film. Interestingly, The Same Difference does not recur to stereotypical images of these black queer female gender presentations. By doing so, Onourah challenges the supposed homogeneity of the black community as well as the whiteness of queerness. Four non-traditional stud women are the center of attention in The Same Difference. Their lives and everyday struggles of being marginalized within an already marginalized community are portrayed in more detail: Jordan, a pregnant stud, struggles with the discrimination of an online acquaintance who is repelled by Jordan's pregnancy. King Kellz is an entertainer who identifies as stud but wears weaves and is discriminated against because of her feminine looking hair. Mercedes, a bisexual woman, is scared to introduce her new boyfriend to her lesbian friends, and Felicitas "Snoop" Pearson, who some viewers might recognize from The Wire,presents shaky attempts to walk in heels in preparation for a feminine role in a movie that stands in sharp contrast to her otherwise masculine presentation. These stories are interspersed with sequences in which other studs offer their opinions on the rigid rules for acceptable desire in the black lesbian community that come with these gender representations. The rules that the filmmaker chooses to address are: "you have to be either stud or femme, nothing in-between," "no stud on stud," and "no bisexuals." Each new rule is introduced in white letters on black title slides which reminds the viewer of other documentaries speaking to the black queer existence, most famously Jenny Livingston's Paris Is Burning (1989), but also Daniel Peddle's The Aggressives (2005). Both films use title slides to categorize the experiences traced on screen. In The Same Difference, the title slides function as Onourah's explicit interaction with the construction of her film. They provide a clear framing for the statements of her subjects but also act as a visual reminder of the borders that divide the community.

The title slide rules are rarely discussed or questioned by the talking heads in the documentary. They are simply subjectively commented upon. This recalls Bill Nichols, who states that "[p]erformative documentary underscores the complexity of our knowledge of the world by emphasizing its subjective and affective dimensions" (202). The Same Difference thus offers its audience "a sense of emphatic engagement that overshadows [its] reference to the historical world" (Nichols 94). Onourah counts on the emphatic engagement by leaving most subjective comments undiscussed, simply appealing to the affect of the viewer. The only profounder discussions take place during the scenes that center the four subjects that Onourah follows more closely. These stud women who wear weaves, become pregnant, date men, or perform femininity are also those women who seemingly transgress the community's rigid borders and rules through their queer desire or gender performance.

\subsection{Queering Black Masculinity}

At5a time when black masculinity and white queerness are at the center of debate, Onourah forces black queer women into the center of the frame, but not without struggle. "Historically, black women have reacted to this repressive force of hegemonic discourses on race and sex with silence, secrecy, and a partially self-chosen invisibility" (Hammonds 142). Responding to these "politics of silence," ${ }^{15}$ Onourah 
centers black female sexuality at the same time as she queers traditional notions of black masculinity "as simultaneously 'hypermasculine' and 'effeminate"' (Gavanas 134) through her focus on black female studs. She counters the rigidity with which nonnormative performances are sanctioned within the community with the multiplicity of expressions of black queerness and gender variance that the studs represent on screen and undermine the rigid rules ("there is a rulebook") that some of the women have. By doing so, the filmmaker answers Evelynn Hammonds's call that "we need a methodology that allows us to contest rather than reproduce the ideological system that has up to now defined the terrain of black women's sexuality" (144). The Same Difference breaks new ground in its depiction of black women's sexuality. Not only with regard to the "politics of silence" that it clearly defies, but also with regard to the dominance of (hetero)normative gender presentation and sexuality. Most of the black queer women in the documentary defy stereotypical representations of femininity and masculinity. Those who present as femme in the documentary are clearly outnumbered by those who present as masculine, giving masculinity a certain focus. Gender roles are the presumed basis for the women's relationships with other (black) queer women. The given rules are simple: masculine identified lesbians form relationships with female identified women. Femme on femme couples and stud on stud couples are equally degraded. The discriminatory practices against relationships outside the stud/femme paradigm is reflected in the clear disgust that some of the talking heads express in the film. These women question the authenticity of femme/femme or stud/stud relationships and nontraditional gender representations, for example femme aggressive, on the basis of their transgression of the community's rules of acceptable behavior. The transformative potential that these supposedly non-normative relationships and identifications have toward queerness and blackness are left undiscussed. Instead, heterosexuality and black masculinity seem to be a guiding principle for the presentation of black lesbian couples, suggesting a strategically deployed construct that reflects a particular type of masculinity performed by black males and which in turn grants some access to power or can be used as a defense mechanism against oppression. There are, however, interesting exceptions to these stereotypical representations of black masculinity. In a very intriguing scene, introduces Nykya and Mickey, a stud on stud couple, confront a stud friend who believes that their relationship "is so nasty." The explanation their friend gives hinges between the comic and the deeply hurtful when she claims that there is indeed a rulebook which says gay relationships should always be stud and femme. This scene is followed by short sequences of other talking heads explaining that stud on stud couples are viewed as "faggots in the gay community." This opens up two possible areas of explanation. The disgust shown for something gay suggests to a reverence of heterosexuality which is only properly represented through a stud/femme couple, but degraded through a stud/stud or femme/femme couple. Second, the expression "that is gay" is racialized to a certain extent because it fears the emasculation of blackness.

The intricacies of race as it intersects with expressions of masculinity, femininity, and queerness in the black lesbian community are left undiscussed by the filmmaker although the performances of femininity and masculinity are clearly shaped through blackness. Presenting as stud is impossible in this context without blackness, as opposed to presenting as butch which is also used in the white lesbian community. Femininity, however, as it is presented in the documentary, is never racialized because 
the term femme is used by white lesbians and black lesbians alike throughout the film without relating it to a racialized context in which each femme is located.

Black masculinity, thus, plays an important identificatory role in the black lesbian community that also offers transgressions from stereotypical constructs that assume black masculinity as always heterosexual. The black masculinity that the studs in The Same Difference perform thus deconstructs blackness and heterosexual masculinity, problematizing both identifications at the same time as rendering them stereotypical at times. It is within these performances of black masculinity by black queer women, however, that a certain border cannot be transgressed. This border is the authenticity of black masculinity in which authentic blackness is inherently tied to authentic masculinity (Harper). This is reflected in the disgust shown for apparently emasculating 'gay' expressions as in stud on stud relationships. It is also depicted through other non-normative expressions of gender that challenge a presumed authentic masculinity, for instance wearing a weave, as King Kellz does, and becoming pregnant, as Jordan does. Kai Davis, one of the protagonists in The Same Difference agrees, that there is a certain "reverence towards masculinity." Authentic masculinity is the framework through which all deviations (weaves, pregnancy, gayness) are perceived. This reverence toward masculinity that most of the protagonists of the film share, also enables a denigration of femininity that the film never critiques although it clearly centers nontraditional femininity. It does, however, reveal the complexity of black masculinity as it is both revered and queered through black queer women.

\subsection{Strange Affinities}

The black queer women in The Same Difference disrupt the normative gender expressions and sexualities of a dominant heterosexual majority at the same time as they challenge normative ideas about queerness. Countless couples and individuals that do not stick to the relationship rules, or somehow invalidate authentic masculinity, challenge blackness and queerness simultaneously. The rigid boundaries with which the black lesbian community demarcates acceptable and non acceptable gender presentation and behavior, as the documentary suggests, are nevertheless part of a communal set of rules that regulates belonging and enables collectivity.

The normative ideas of queerness differ across various racialized communities. As the documentary suggests, the identificatory practices of the black queer community are, for example, different from those of the white community. The clear cut border between black and white queer communities is visualized through the title slide 'white lesbians vs black lesbians' and becomes even more apparent in the following, rather unsettling scene. Kate Frawley, a white lesbian party promoter who presents as butch believes, that "a lot of times the gay and lesbian African American women and men go back to what they have already seen in their family network or unit and that's where a lot of the butch/femme comes in. It's like they are trying to be as heterosexual as possible but within their gay lifestyle." Apart from the deeply questionable attempt to appear as an expert on someone else's community, Frawley's statement leaves more room for discussion. Her judgment alludes to an oppressive heterosexuality within the black community, contributing to the stereotypical assumption that black means straight, if not in regard to sexuality than at least in regard to the representation of coupledom. It also alludes to a certain "kind of 
internalized homophobia" as one of the black lesbian women also suggests, which is performed through stud/femme couples.

The filmmaker's choice to include a sequence in which white lesbians comment on the relationship structures of the black lesbian community and vice versa, shows the clear cut between both queer communities. Aesthetically and narratively the documentary does not enter into a debate to bring black queerness and white queerness into contact with each other. Instead, the rift is left undiscussed although the comments from both black and white lesbians clearly show similarities in the discriminatory practices of both communities. Aesthetically, the sequence marks a break from self-criticizing and self-affirming black lesbian voices, to an outsider's view in which the prerogative of whiteness is left unchallenged. This prerogative of whiteness, if not discussed explicitly, is made visible through the documentary not only on a thematic level, but also on a material level. The screening of The Same Difference at LGBT film festivals around the U.S. and outside of its national boundaries, engages with the lack of racial diversity in predominantly white audiences at these festivals as much as it engages with the presumed heterosexuality of the black community (Gamson 246-247).

The context of the documentary makes clear that when the women talk about the community, they are not referring to a pan-ethnic, multi-racial, multi-gendered queer community. Instead, they are referring to a black lesbian community on the margins of society in which non-normative gender presentations are as much stigmatized as they are in the heterosexual community. Blu Semper reminds the audience, that "the only group of people who have these types of idiosyncrasies are African American lesbians [although] black lesbians are already leading an unacceptable life" (The Same Difference). These idiosyncrasies are placed into a mix of slips of comments, opinions, and unfinished arguments. The individual shots of black lesbians convey a certain subjectivity with regard to their monologues that expresses the need for individuality, but taken together they also transmit a certain sense of community. By doing so, The Same Difference does not evoke a utopian feel of community, but instead stays highly critical of community without disregarding it completely.

The need to identify with something other than lesbian becomes very clear in the documentary, as most of the women use additional descriptive markers such as stud, aggressive, or femme, while performatively engaging with a black queer identity. For example, King Kellz, the weave wearing stud entertainer who cries in front of the camera nevertheless clearly identifies as stud. The pregnant stud also does not stay away from identifying as stud, although her pregnancy is perceived by many as impossible. There is somehow a clear need to broaden the possibilities given within each identification without challenging the identificatory practices of the black lesbian community as such. The number of rules within the black lesbian community thus not only hinder belonging, they also speak to a certain need for a sense of belonging that ultimately enable collectivity. They recall Cohen's statement that "the roles of identity and community as paths to survival" (45) are important, especially in a time when the individualization of the mainstream (white) queer community ignores the need for intersectional analysis. 


\subsection{Collective Action}

While The Same Difference on the surface stays out of the political in the sense that it discusses identification within the black lesbian community without relating these identifications to a broader political agenda, it does, however, hint at the messy terrain that is politics. Performatively engaging with the intersectional nature of identities is part of a political project that aims to restructure the world not only along the lines of hetero vs. queer, but also along the lines of race, class, and gender. The queerness of blackness that places blackness under attack within a dominant U.S. society is underscored through the performance of black queerness. At the same time, blackness is broadened, challenged, and empowered through the performance of black masculinity by black queer women. Queerness, in this case, is not simply a by-product of black lesbian womanhood. It is a conscious act to destabilize both blackness and queerness in an attempt to broaden their possibilities. Black queerness as it is performed differently by each woman on screen, is an essential deconstructing tool for masculinity, femininity, queerness, and blackness and by extension political.

The filmic representation of the discriminatory practices of the black lesbian community thus counters the social and exclusionary methods used by a mainstream, white queer movement to uphold systems of racial and national belongings and hegemonic models of citizenship. It does not tell stories critical of the mainstream, thus leaving the mainstream in the center. Instead, it brings a critical, non-normative, marginal aspect of queerness back into a position from which it can be critical of the mainstream.

Although broad in its thematic approach, aesthetically the documentary mostly fails to convey a link to the historical and political realities that clearly shape the identifications of the black lesbian women on screen. This link, that is so common in performative documentary, is only conveyed through the closing statements of various different talking heads who state, "none of us are like each other," "that is the uphill battle that we have been fighting for so long," and "we all need to come together for the greater good and work together to advance our movement." Onourah leaves it to the audience to decide to whom her subjects speak to when they refer to "our movement," a black lesbian movement, a black liberation movement, or a movement that is informed by blackness and queerness simultaneously.

\section{Conclusion}

The marginalization of queerness prevalent in the beginnings of queer activism has been followed by a period of increasing acceptance into the nation-state, often at the expense of racial justice. The social and political claims at stake in the current moment of colorblindness within the queer community do nothing less than lead to the disposal of one population in favor of the incorporation of another, leaving those at the intersections invisible, unattended to, and erased, except by a few brave scholars, artists, and activists. The invisibility of black queerness and queer blackness is challenged by this paper and the arguments it makes in relation to the history of queerness, the \#BlackLivesMatter movement and Onourah's documentary The Same Difference. They all show that the pre-existing assumptions of collective identities that films like The Same Difference but also movements like \#BlackLivesMatter challenge and 
the unruliness with which black queerness is performed in both, echoes Omi and Winant's understanding of race as an "unstable and 'decentered' complex of social meanings constantly being transformed by political struggle" (Omi and Winant 110). In other words, Onourah and the activists of \#BlackLivesMatter restore the transgressive potential of blackness and/as queerness by understanding both race and sexuality in a decentered way, constantly in need of redefinition. They invite us to understand why a queer critique that does not account for blackness is not enough to re-queer anything.

Radical queerness does not stay away from the messy social struggles that concern those on the margins of dominant society. From the position of the most marginalized within dominant black and queer discourse, true intersectional critique can best be developed and a re-queering of the nation can and must take place. Exploring black queerness from the perspective of black queer women fills a void in the representation of blackness and queerness. It enables a critique of mainstream queer theory that is rooted in women of color feminism and critical race studies and opens up the possibility to put queerness into a critical position toward the state which grants queerness more and more rights while blackness moves further toward death.

Reequeering the nation requires a version of queerness that is critical of the racist assumptions of a colorblind state, not complicit with it. Queerness generates its most powerful critique when speaking from a marginalized position which acknowledges the material realities of intersectional experiences. In practical terms this means black queer movements are "forced to reconcile [their] theoretical and experiential knowledge, and challenged to come up with new ways of understanding and practicing the intersectionality that... shape[] our table" (Riggs 187). Only then can a re-queering take place and queer thinking can develop its most forceful critique to encourage a properly angled queer lens that analyzes how heteronormative systems of power function through the production and taxonomy of racialized, gendered, sexualized, and classed behaviors and practice.

\section{BIBLIOGRAPHY}

Alexander, Michelle. The New Jim Crow: Mass Incarceration in the Age of Colorblindness. New York: The New Press, 2012. Print.

---. Roots of Today's Mass Incarceration Crisis Date to Slavery, Jim Crow. 4 Mar 2015. Web. 23 Apr 2016.

http://www.democracynow.org/2015/3/4/michelle_alexander_roots_of_todays_crisis.

Appiah, Kwame Anthony. "Identity, Authenticity, Survival: Multicultural Societies and Social Reproduction." Multiculturalism: Examining the Politics of Recognition. Ed. Amy Gutmann. Princeton: Princeton University Press, 1994. 149-163. Print.

Bassichis, Morgan, and Dean Spade. “Queer Politics and Anti-Blackness.” Queer Necropolitics Ed. Jin Haritaworn, Adi Kunstman, and Silvia Posocco. New York: Routledge, 2014. 191-210. Print. 
Brother to Brother. Dir. Rodney Evans. Peccadillo Pictures, 2010. DVD.

Carpenter, Dale. “The Unknown Past of Lawrence v Texas.” Michigan Law Review 102 (2004): 1464-1527. Print.

Coates, Ta-Nehisi. Between the World and Me. New York City: Spiegel \& Grau, 2015. Print.

Cohen, Cathy. "Punks, Bulldaggers, and Welfare Queens." Black Queer Studies: A Critical Anthology. Ed. Johnson, EP and Henderson, MG. Duke University Press: Durham and London, 2005. 21-55. Print.

---. Democracy Remixed. Black Youth and the Future of American Politics. New York: Oxford University Press, 2011. Print.

Crenshaw, Kimberly. "Mapping the Margins: Inter-sectionality, Identity Politics, and Violence Against Women of Color." Stanford Law Review 43.6 (Jul. 1991): 1241-1299. Print.

Duggan, Lisa. The Twilight of Economy: Neoliberalism, Cultural Politics, and the Attack on Democracy. Boston: Beacon Press, 2003. Print.

Egan, Patrick J., and Kenneth Sherrill. "California's Proposition 8: What Happened and What Does the Future Hold?” National Gay and Lesbian Task Force Institute, Jan 2015. Web. 15 Nov 2016.

Eng, David L. The Feeling of Kinship: Queer Liberalism and the Racialization of Intimacy. Durham and London: Duke University Press, 2010. Print.

Foucault, Michel. The History of Sexuality: Volume 1. Trans. Robert Hurley. New York: Vintage Random House, 1990. Print.

Friedman, Susan Stanford. Mappings: Feminism and the Cultural Geographies of Encounter. Princeton: Princeton University Press, 1998. Print.

Gamson, Joshua. "The Organizational Shaping of Collective Identity: The Case of Lesbian and Gay Film Festivals in New York.” Sociological Forum 11.2 (June 1996): 231-261. Print.

Garza, Alicia. “A Herstory of the \#BlackLivesMatter Movement.” The Feminist Wire. Web. 27 Aug 2016.

http://www.thefeministwire.com/ 2014/10/blacklivesmatter-2/

Gavanas, Anna. Fatherhood Politics in the United States: Masculinity, Sexuality, Race, and Marriage. Urbana and Chicago: University of Illinois Press, 2004. Print.

Gibran Muhammad, Khalil. The Condemnation of Blackness: Race, Crime, and the Making of Modern Urban America. Cambridge and London: Harvard University Press, 2011. Print.

Hall, Stuart. “What is this ‘Black' in Black Popular Culture?” Social Justice 20.1-2 (1993): 104-114. Print.

Hammonds, Evelynn. "Black (W)holes and the Geometry of Black Female Sexuality." Feminism Meets Queer Theory. Ed. Elizabeth Weed and Naomi Schor. New York and London: New York University Press, 2000. 136-156. Print.

Hanhardt, Christina B. Safe Space: Gay Neighborhood History and the Politics of Violence. Durham: Duke University Press, 2013. Print.

Harper, Philip Brian. Are We Not Men? Masculine Anxiety and the Problem of African-American Identity. New York and Oxford: Oxford University Press, 1996. Print. 
Harper, Phillip Brian, Anne McClintock, José Esteban Muñoz, and Trish Rosen. “Queer Transexions of Race, Nation, and Gender: An Introduction." Social Text 52/53.3-4 (Fall/Winter 1997): 1-4. Print.

Hartman, Saidiya V. Scenes of Subjection. Terror, Slavery, and Self-Making in Nineteenth-Century America. New York and Oxford, Oxford University Press, 1997. Print.

hooks, bell. “An Aesthetic of Blackness: Strange and Oppositional." Lenox Avenue: A Journal of Interarts Inquiry 1 (1995): 65-72. Print.

HoSang, Daniel. Racial Propositions: Ballot Initiatives and the Making of Postwar California. Berkeley and Los Angeles: University of California Press, 2010. Print.

Lorde, Audre. Sister Outsider: Essays and Speeches by Audre Lorde. Berkeley: Crossing Press, 2007. Print.

Muñoz, José Esteban. Cruising Utopia: The Then and There of Queer Futurity. New York and London: New York University Press, 2009. Print.

Nichols, Bill. Introduction to Documentary. Bloomington: Indiana University Press, 2010. Print. Omi, Michael, and Howard Winant. Racial Formations in the United States. New York: Routledge, 2015. Print.

Puar, Jasbir K. Terrorist Assemblages: Homonationalism in Queer Times. Durham and London: Duke University Press, 2007. Print.

Riss, Reuben. "Meeting Queerness and Blackness in Ferguson." QED: A Journal in GLBTQ Worldmaking 2.2 (Summer 2015): 184-192. Print.

Sexton, Jared. "People-of-Color-Blindness: Notes on the Afterlive of Slavery." Social Text 28.2 (Summer 2010): 31-56. Print.

Spade, Dean. “Documenting Gender.” Hastings Law Journal 59.4 (March 2008): 731-842. Print.

Stanley, Fred. L, and Louis H. Pratt, Eds. Conversations with James Baldwin. Jackson and London: University of Mississippi Press, 1989. Print.

The Same Difference. Dir. Nneka Onourah.

\section{NOTES}

1. The slogan appeared on the title page of the Advocate in December 2008.

2. Homonormativity is a term coined by Lisa Duggan in The Twilight of Economy (2003) to describe the growing tendency of mostly white, middle-class queer people to integrate into dominant society rather than challenging its institutions.

3. The broad range of literature on identity and its discontents is too much to mention here. Authors that this paper's critical understanding is based on include Linda Martin Alcoff, Gloria Anzaldúa, Anthony Appiah, Gayatri Spivak, Shane Phelan, bell hooks, and many more.

4. I want to incorporate an understanding of queerness into the critical endeavor across the intersection of blackness and queerness that is aware of the racial dynamics that have shaped the social and cultural markup of U.S. society, especially blackness.

5. Foucault calls this the "action of the norm" (144) which takes over regulatory functions from the law. 
6. Rodney Evans's narrative film Brother to Brother is a notable exception. His film aims to write black queerness into collective memory through tracing the story of Richard Bruce Nugent from the Harlem Renaissance to the present.

7. Fictive only because the riots at the Stonewall Inn in New York City have only been one riot among many others during the 1960s that all resulted from similar crises.

8. Lawrence vs. Texas (2003) was a Supreme Court decision that struck down sodomy laws first in Texas and then thirteen other States, making same-sex sexual activity legal in every U.S. state. Brown vs. Board of Education (1954) was a Supreme Court legal decision that declared segregation in schools unconstitutional. In Loving vs. Virginia (1967), the Supreme Court struck down the prohibition of interracial marriage as unconstitutional.

9. Ironically, the fact that one of the plaintiffs in Lawrence vs. Texas was a black gay man hardly ever received any attention except in the event itself that led to the decision. Dale Carpenter looks at the unknown past of Lawrence v. Texas in which it becomes clear that the police were ordered to the place of the events because there was "a nigger going crazy with a gun" (1509).

10. http://blacklivesmatter.com/about/

11. The Human Rights Campaign (HRC) for example was recently investigated by The Pipeline Project and called a "white man's club."

12. Proposition 8 is a state constitutional amendment that made same-sex marriage unconstitutional in the state of California

13. See Egan and Sherrill for a complete analysis of Proposition 8. Also available as download at http://www.thetaskforce.org/static_html/downloads/issues/egan_sherrill_prop8_1_6_09.pdf

14. The term stud is used to describe a lesbian woman who presents as more masculine. In contrast, femme describes a lesbian woman who presents as feminine. Butch is often used interchangeably with stud. However, stud is always racialized through blackness.

15. Historian Evelyn Brooks Higginbotham used the term the 'politics of silence' to describe the silence of black women and their political strategy to promote Victorian morality in their effort to reshape the image of the sexually immoral black woman.

\section{ABSTRACTS}

This paper traces the historical context of queer activism and black activism from the social movements of the 1960s and 1970s in the U.S. in order to show the deep rift between blackness and queerness that comes into full force in a supposedly colorblind nation that more than once claimed that "gay is the new black." This is not only a dangerous analogy that lacks profound grounding, it also leads to a discourse that draws a clear boundary between two separate communities and movements-one black, one queer. Recent activism by \#BlackLivesMatter has challenged the analogy of blackness and queerness by centralizing both in their critique of statesanctioned violence against black people. The analysis of Nneka Onourah's documentary The Same Difference provides further insight into the complex array of power that affect the lived experiences at the intersection of queerness, blackness, and gender. The documentary generates points of departure through which queerness finds validity as a tool for critical thinking, a way of active resistance, and a basis for community action. Placing the documentary in context, this article reconstructs a paradigm for radical queer politics in the force-field of traditional notions of black masculinity and femininity and queerness as a destabilizer of both, bringing queerness back into a marginal position from which it can be critical of the state. 
INDEX

Keywords: blackness, community, femininity, masculinity, non-normative gender, politics, queerness, race

\section{AUTHOR}

ELENA KIESLING

University of Mannheim 